\title{
MENINGKATKAN KUALITAS PEMBELAJARAN SEJARAH INDONESIA MENGGUNAKAN MODEL SNOWBALL THROWING DENGAN MEDIA AUDIO VISUAL
}

\author{
Hayatun Nufus \\ SMA Negeri 2 Sampang \\ Email: hayatunnufus@yahoo.com
}

\begin{abstract}
Abstrak:
Sejarah Indonesia adalah ilmu yang mengkaji seperangkat peristiwa, fakta, konsep, dan generalisasi yang berkaitan dengan isu sosial. Berdasarkan data awal selama dalam proses pembelajaran, ditemukan fakta bahwa pembelajaran Sejarah Indonesia tidak berkualitas ditunjukkan guru belum mengembangkan pembelajaran inovatif, kurang memanfaatkan media pembelajaran akibatnya siswa kurang aktif dalam mengikuti pembelajaran dan hasil belajar siswa rendah yaitu $61,5 \%$ siswa tidak tuntas. Solusi untuk memecahkan masalah tersebut dengan menerapkan PTK menggunakan model Snowball Throwing dengan media Audio Visual. Penelitian dilaksanakan sebanyak 2 siklus. Setiap siklus terdiri dari 2 kali pertemuan meliputi tahap perencanaan, pelaksanaan tindakan, observasi dan refleksi. Subyek penelitian ini adalah guru dan siswa kelas XI. Teknik pengumpulan data dalam penelitian ini yaitu teknik tes dan non tes yang terdiri dari observasi, dokumentasi, wawancara dan catatan lapangan. Hasil penelitian menunjukkan adanya peningkatan kualitas pembelajaran Sejarah Indonesia. Pada siklus I ratarata skor keterampilan guru adalah 25,5 (kategori baik), rata-rata skor aktivitas siswa 20,3 (kategori baik), rata-rata nilai hasil belajar siswa 67,69 dengan ketuntasan klasikal 69,23 \%. Pada siklus II, rata-rata skor keterampilan guru 35,5 (kategori sangat baik), rata-rata skor aktivitas siswa 26,2 (kategori baik), rata-rata hasil belajar 81,93 dengan ketuntasan klasikal 84,62 \%. Simpulan penelitian ini yaitu model Snowball Throwing dengan media Audio Visual dapat meningkatkan kualitas pembelajaran Sejarah Indonesia yang meliputi keterampilan guru, aktivitas siswa dan hasil belajar siswa.
\end{abstract}

Kata Kunci: Kualitas Pembelajaran, Snowball Throwing, Media Audio Visual

\begin{abstract}
:
History of Indonesia is a science that examines a set of events, facts, concepts, and generalizations related to social issues. Based on preliminary data during the learning process, it was found that learning history of Indonesia is not qualified indicated that teachers have not developed innovative learning, less use of learning media consequently less active students in following learning and low student learning result that is $61,5 \%$ student unfinished. Solution to solve the problem by applying class action research using Snowball Throwing model with Audio Visual media. The study was conducted in 2 cycles. Each cycle consists of two meetings covering the planning, implementation, observation and reflection. The subjects of this study are teachers and students of class XI. Data collection techniques in this study are test and non-test techniques consisting of observation, documentation, interviews and field notes. The result of the research shows the improvement of
\end{abstract}


learning quality of Indonesian history. In the first cycle the average teacher skill score is 25.5 (good category), the average student activity score is 20.3 (good category), the average score of student learning result is 67,69 with $69,23 \%$ classical completeness. In cycle II, the average score of teacher skill 35,5 (very good category), average score of student activity 26,2 (good category), average of result of learning 81,93 with classical completeness $84,62 \%$. The conclusion of this research is Snowball Throwing model with Audio Visual media can improve the quality of learning History of Indonesia which includes teacher skills, student activities and student learning outcomes.

Keywords: Learning Quality, Snowball Throwing, Audio Visual Media.

\section{Pendahuluan}

Berdasarkan Peraturan Menteri Pendidikan Nasional Nomor 22 Tahun 2006 tentang Standar Isi untuk Satuan Pendidikan Dasar dan Menengah menyatakan bahwa Sejarah merupakan cabang ilmu pengetahuan yang menelaah tentang asal-usul dan perkembangan serta peranan masyarakat di masa lampau berdasarkan metode dan metodologi tertentu. Terkait dengan pendidikan di sekolah dasar hingga sekolah menengah, pengetahuan masa lampau tersebut mengandung nilai-nilai kearifan yang dapat digunakan untuk melatih kecerdasan, membentuk sikap, watak dan kepribadian peserta didik. ${ }^{1}$

Mata pelajaran Sejarah Indonesia telah diberikan pada tingkat pendidikan dasar sebagai bagian integral dari mata pelajaran IPS, sedangkan pada tingkat pendidikan menengah diberikan sebagai mata pelajaran tersendiri. Mata pelajaran Sejarah Indonesia memiliki arti strategis dalam pembentukan watak dan peradaban bangsa yang bermartabat serta dalam pembentukan manusia Indonesia yang memiliki rasa kebangsaan dan cinta tanah air.

Berdasarkan Permendiknas Nomor 41 Tahun 2007 tentang Standar Proses Untuk Satuan Pendidikan Dasar dan Menengah dijelaskan bahwa pelaksanaan pembelajaran merupakan implementasi dari RPP. Pelaksanaan pembelajaran meliputi kegiatan pendahuluan, kegiatan inti dan kegiatan penutup. Pelaksanaan kegiatan inti merupakan proses pembelajaran untuk mencapai KD yang dilakukan secara interaktif, inspiratif, menyenangkan, menantang, memotivasi peserta didik untuk berpartisipasi aktif, serta memberikan ruang yang cukup bagi prakarsa, kreativitas, dan kemandirian sesuai dengan bakat, minat dan perkembangan fisik serta psikologis peserta didik. Kegiatan inti menggunakan metode yang disesuaikan dengan karakteristik peserta didik dan mata pelajaran, yang dapat meliputi proses eksplorasi, elaborasi, dan konfirmasi. ${ }^{2}$

Berdasarkan pengalaman pembelajaran secara langsung yang dilakukan oleh peneliti selama kegiatan penelitian dan hasil wawancara serta observasi bersama tim kolaborator terhadap pembelajaran Sejarah Indonesia kelas XI-MIPA3 SMA Negeri 2 Sampang, ditemukan fakta bahwa proses pembelajaran Sejarah Indonesia dapat dikatakan tidak berkualitas. Hal ini ditunjukkan guru sudah menggunakan model pembelajaran yang inovatif tetapi belum mengembangkannya secara maksimal sesuai dengan kebutuhan siswa, guru

\footnotetext{
${ }^{1}$ Depdiknas, Permendiknas Nomor 22 Tahun 2006, (Jakarta: BSNP, 2006), 16.

2 Depdiknas, Permendiknas Nomor 41 Tahun 2007, (Jakarta: BSNP, 2007), 34.
} 
kurang memanfaatkan media untuk mendukung kegiatan pembelajaran serta kurang adanya motivasi dari guru kepada siswa untuk aktif dalam kegiatan pembelajaran di dalam kelas. Hasil observasi di lapangan juga ditemukan fakta bahwa pada saat proses pembelajaran, siswa kurang aktif dalam mengikuti kegiatan pembelajaran yang ditunjukkan dengan kurang adanya interaksi timbal balik antara guru dengan siswa, siswa merasakan ada kejenuhan sehingga menyebabkan beberapa di antaranya membuat gaduh dan mengganggu konsentrasi siswa lain, kurangnya penguasaan materi pelajaran serta kurangnya kedisiplinan siswa dalam mengikuti kegiatan pembelajaran, siswa tidak berani bertanya kepada guru tentang materi yang belum dimengerti juga belum bisa bekerja sama dalam kelompok secara maksimal.

Keadaan tersebut juga didukung dengan data kuantitatif, berdasarkan data hasil evaluasi belajar siswa kelas XI-MIPA-3 SMA Negeri 2 Sampang tahun ajaran 2016/2017 dalam pembelajaran Sejarah Indonesia menunjukkan bahwa sebanyak 61,5\% (24 dari 39 siswa) mendapatkan nilai dibawah KKM yang telah ditetapkan yaitu 60 . Dengan kata lain hanya 38, 5\% siswa yang mengalami ketuntasan. Nilai terendah yang didapat adalah 40 sedangkan nilai tertinggi adalah 87,5 , dengan nilai rerata kelas yaitu 63,3. Hal ini perlu mendapat perhatian khusus mengingat bahwa Sejarah Indonesia sebagai salah satu mata pelajaran di sekolah menengah merupakan mata pelajaran yang berperan penting untuk membentuk peserta didik yang tidak hanya memiliki kecerdasan intelektual namun juga memiliki keterampilan bersosialisasi dengan masyarakat dalam kehidupan sehari-hari. Dengan melihat data hasil observasi dan hasil evaluasi pembelajaraan Sejarah Indonesia tersebut, maka perlu diadakan perbaikan pembelajaran agar dapat meningkatkan kualitas pembelajaran.

Berdasarkan hasil diskusi dan masukan beberapa guru kelas XI-MIPA-3 SMA Negeri 2 Sampang untuk memecahkan masalah yang ditemukan di lapangan, tim kolaborator menetapkan alternatif tindakan untuk meningkatkan kualitas pembelajaran Sejarah Indonesia dengan mendorong keterlibatan siswa untuk aktif dalam kegiatan pembelajaran serta meningkatkan keterampilan guru menggunakan model Snowball Throwing dengan media Audio Visual.

Dari ulasan latar belakang di atas, maka peneliti akan melakukan penelitian tindakan kelas dengan judul "Meningkatkan Kualitas Pembelajaran Sejarah Indonesia Menggunakan Model Snowball Throwing dengan Media Audio Visual Pada Siswa Kelas XI-MIPA-3 SMA Negeri 2 Sampang Semester Genap Tahun Pelajaran 2016/2017."

\section{Tinjauan Teori}

\section{Kualitas Pembelajaran}

Menurut Jihad dan Haris menyatakan bahwa pembelajaran merupakan suatu proses yang terdiri dari kombinasi dua aspek, yaitu belajar tertuju kepada apa yang harus dilakukan oleh siswa, mengajar berorientasi pada apa yang harus dilakukan oleh guru sebagai pemberi pelajaran. Kedua aspek ini akan berkolaborasi secara terpadu menjadi suatu kegiatan pada saat terjadi interaksi 
antara guru dengan siswa, serta antara siswa dengan siswa di saat pembelajaran sedang berlangsung. ${ }^{3}$

Hamdani menjelaskan bahwa pembelajaran secara umum adalah kegiatan yang dilakukan guru sehingga tingkah laku siswa berubah ke arah yang lebih baik. Pembelajaran adalah upaya guru menciptakan iklim dan pelayanan terhadap kemampuan, potensi, minat, bakat dan kebutuhan siswa yang amat beragam agar terjadi interaksi optimal antara guru dan siswa serta antarsiswa. ${ }^{4}$

Sedangkan menurut Uno dan Mohamad, pembelajaran yang efektif ditandai dengan berlangsungnya proses belajar dalam diri siswa. Oleh karena itu, agar kemampuan siswa dapat dikontrol dan berkembang semaksimal mungkin dalam proses belajar di kelas maka program pembelajaran tersebut harus dirancang terlebih dahulu oleh para guru dengan memperhatikan berbagai prinsip-prinsip pembelajaran yang telah diuji keunggulannya. ${ }^{5}$

Dari beberapa pendapat di atas mengenai pembelajaran, dapat disimpulkan bahwa pembelajaran merupakan interaksi antara guru sebagai pengajar dan siswa sebagai pebelajar. Interaksi diantara keduanya terjadi melalui pemberian pelayanan oleh guru terhadap kemampuan, bakat dan minat yang dimiliki siswanya dengan merancang proses pembelajaran yang tepat sehingga tujuan dari proses pembelajaran di dalam kelas dapat tercapai secara optimal.

Slameto juga mengemukakan bahwa belajar adalah suatu proses usaha yang dilakukan seseorang untuk memperoleh perubahan tingkah laku yang baru secara keseluruhan, sebagai hasil pengalamannya sendiri dalam interaksi dengan lingkungannya. ${ }^{6}$

Sedangkan menurut Arsyad belajar adalah suatu proses yang kompleks yang terjadi pada diri setiap orang sepanjang hidupnya.Proses belajar itu terjadi karena adanya interaksi antara seseorang dengan lingkungannya. Oleh karena itu, belajar dapat terjadi kapan saja dan di mana saja. Salah satu pertanda bahwa seseorang itu telah belajar adalah adanya perubahan tingkah laku pada diri orang itu yang mungkin disebabkan oleh terjadinya perubahan pada tingkat pengetahuan, keterampilan dan sikapnya. ${ }^{7}$

Berdasarkan pendapat di atas, peneliti dapat menyimpulkan bahwa belajar merupakan suatu proses yang dialami oleh setiap orang di sepanjang hidupnya sebagai hasil interaksi dengan lingkungan sekitar yang mampu membawa perubahan pada aspek pengetahuan (kognitif), keterampilan (psikomotorik) dan sikap (afektif).

Menurut Anitah, dkk supaya belajar terjadi secara efektif perlu diperhatikan beberapa prinsip: (1) Motivasi; (2) Perhatian atau pemusatan energi psikis terhadap pelajaran erat kaitannya dengan motivasi; (3) Aktivitas; (4) Balikan; dan (5) Perbedaan Individual. Guru hendaknya mampu memperhatikan dan melayani siswa sesuai dengan karakteristik mereka masing-masing. ${ }^{8}$ Sedangkan menurut Uno, banyak ahli yang mengemukakan tentang prinsip belajar yang memiliki

\footnotetext{
${ }^{3}$ Asep Jihad dan Abdul Haris, Evaluasi Pembelajaran, (Yogyakarta: Multi Pressindo, 2008), 11.

${ }^{4}$ Hamdani, Strategi Belajar Mengajar, (Bandung.Pustaka Setia, 2011), 167.

${ }^{5}$ Hamzah Uno, Perencanaan Pembelajaran, (Jakarta: Bumi Aksara, 2009), 145.

6 Slameto, Belajar dan Faktor-faktor yang Mempengaruhinya, (Jakarta: Rineka Cipta, 2010), 2.

${ }^{7}$ Azhar Asyhar, Media Pembelajaran, (Jakarta: Rajawali Pers, 2011), 10.

${ }^{8}$ Sri Anitah W., Strategi Pembelajaran di SMA, (Jakarta: Universitas Terbuka, 2009), 1.17.
} 
persamaan dan perbedaan. Akan tetapi, secara umum terdapat beberapa prinsip dasar yaitu: (1) Perhatian; (2) Motivasi; (3) Keaktifan; (4) Keterlibatan langsung atau pengalaman; (5) Pengulangan; (6) Tantangan; (7) Balikan atau penguatan; (8) Perbedaan individual. ${ }^{9}$

Dari dua pendapat di atas mengenai prinsip-prinsip belajar, peneliti dapat menyimpulkan bahwa tercapainya tujuan pembelajaran sangat berpedoman pada prinsip-prinsip belajar yang pada dasarnya tidak hanya memerlukan peran dari siswa sebagai pebelajar namun juga harus ada dukungan atau peranan dari guru. Siswa sebagai pebelajar sekaligus sebagai individu yang memiliki perbedaan dengan yang lain, harus memiliki motivasi dari dalam diri sendiri untuk ikut terlibat dalam kegiatan belajar secara langsung, dan guru memberikan berbagai dukungan melalui perhatian,balikan atau pengulangan serta penguatan.

\section{Model Pembelajaran Snowball Throwing}

Isjoni menyatakan bahwa cooperative learning adalah suatu model pembelajaran yang saat ini banyak digunakan untuk mewujudkan kegiatan belajar mengajar yang berpusat pada siswa (studend oriented) terutama untuk mengatasi permasalahan yang ditemukan guru dalam mengaktifkan siswa, yang tidak dapat bekerjasama dengan orang lain, siswa yang agresif dan tidak peduli pada orang lain. ${ }^{10} \mathrm{Hal}$ ini sejalan dengan pendapat Rusman bahwa dalam model pembelajaran kooperatif ini, guru lebih berperan sebagai fasilitator yang berfungsi sebagai jembatan penghubung ke arah pemahaman yang lebih tinggi, dengan catatan siswa sendiri. Guru tidak hanya memberikan pengetahuan pada siswa, tetapi juga harus membangun pengetahuan dalam pikirannya. ${ }^{11}$

Snowball Throwing sebagai salah satu model pembelajaran kooperatif merupakan model pembelajaran yang memberikan kesempatan kepada siswa untuk lebih aktif dalam mengikuti kegiatan pembelajaran. Komalasari mengemukakan bahwa Snowball Throwing merupakan model pembelajaran yang menggali potensi kepemimpinan siswa dalam kelompok dan keterampilan membuat-menjawab pertanyaan yang di padukan melalui satu permainan imajinatif membentuk dan melempar bola salju. ${ }^{12}$

Berdasarkan beberapa pendapat di atas dapat disimpulkan bahwa Snowball Throwing merupakan salah satu model pembelajaran kooperatif yang menarik, mampu menggali kepemimpinan siswa dalam kelompok, melatih kemampuan siswa dalam menjawab pertanyaan serta mengandung unsur permainan imajinatif dengan cara siswa menuliskan pertanyaan di lembar kertas, membentuk kertas tersebut hingga menyerupai bola kemudian di lemparkan ke siswa lain.

Adapun langkah-langkah model pembelajaran Snowball Throwing menurut Suprijono adalah sebagai berikut: (1) Guru menyampaikan materi yang akan disajikan; (2) Guru membentuk kelompok-kelompok dan memanggil masingmasing ketua kelompok untuk memberikan penjelasan tentang materi; (3) Masingmasing ketua kelompok kembali ke kelompoknya, kemudian menjelaskan materi yang disampaikan oleh guru kepada temannya. (4) Kemudian, masing-masing

\footnotetext{
${ }^{9}$ Hamzah Uno, Perencanaan Pembelajaran, (Jakarta: Bumi Aksara, 2009), 191.

${ }^{10}$ Isjoni, Cooperative Learning: Efektivitas Pembelajaran Kelompok, (Bandung: Alfabeta, 2012), 16.

11 Rusman, Model-model Pembelajaran, (Jakarta: Rajawali Pers, 212), 201.

${ }^{12}$ Komalasari, Pembelajaran Kontekstual Konsep dan Aplikasi, (Bandung: Refika Aditama, 2011), 67.
} 
siswa diberi satu lembar kerja, untuk menuliskan satu pertanyaan apa saja yang menyangkut materi yang sudah dijelaskan oleh ketua kelompok; (5) Kemudian, kertas tersebut dibuat seperti bola dan dilempar dari satu siswa ke siswa yang lain selama lebih kurang 15 menit; (6) Setelah siswa dapat satu bola/satu pertanyaan, siswa diberi kesempatan untuk menjawab pertanyaan yang tertulis dalam kertas yang berbentuk bola tersebut secara bergantian; (7) Guru memberikan kesimpulan; (8) Evaluasi; dan (9) Penutup ${ }^{13}$

Jadi dapat disimpulkan bahwa model Snowball Throwing memiliki banyak kelebihan jika diterapkan dalam proses pembelajaran karena model Snowball Throwing sangat menarik, menyenangkan, mampu mengembangkan kemampuan berpikir siswa serta membuat siswa menjadi lebih aktif dalam mengikuti kegiatan pembelajaran. Selain memiliki kelebihan, penggunaan model Snowball Throwing dalam kegiatan pembelajaran juga memiliki kekurangan yaitu terjadinya keributan saat siswa melemparkan bola pertanyaan ke arah teman lain.

Kemudian model pembelajaran Snowball Throwing berbasis pada teori belajar konstruktivisme, yang menekankan pada keterlibatan peserta didik dalam proses pembelajaran guna membentuk pengetahuan dari pengalaman yang telah mereka miliki sebelumnya. ${ }^{14}$ Dalam konteks praktik pembelajaran, Snowball Throwing termasuk ke dalam pembelajaran kooperatif (cooperative learning). Dalam pembelajaran kooperatif, belajar dikatakan belum selesai jika salah satu teman dalam kelompok belum menguasai bahan pelajaran. ${ }^{15}$ Secara umum pembelajaran kooperatif lebih dianggap diarahkan oleh guru, dimana guru menetapkan tugas dan pertanyaan-pertanyaan serta menyediakan bahan-bahan dan informasi yang dirancang untuk membantu peserta didik menyelesaikan masalah yang dimaksud. ${ }^{16}$

\section{Media Pembelajaran}

Media adalah perantara atau pengantar pesan dari pengirim kepada penerima pesan. Sedangkan menurut Heinich mengatakan bahwa apabila media itu membawa pesan-pesan atau informasi yang bertujuan instruksional atau mengandung maksud-maksud pengajaran, maka media itu disebut dengan media pembelajaran. ${ }^{17}$

Menurut Anitah dalam kaitannya dengan fungsi media pembelajaran dapat ditekankan beberapa hal berikut: (1) Penggunaan media pembelajaran bukan merupakan fungsi tambahan, tetapi memiliki fungsi sendiri sebagai sarana bantu untuk mewujudkan situasi pembelajaran yang lebih efektif; (b) Media pembelajaran merupakan bagian integral dari keseluruhan proses pembelajaran; (3) Media pembelajaran dalam penggunaannya harus relevan dengan kompetensi yang ingin dicapai dan isi pembelajaran itu sendiri; (4) Media pembelajaran bukan berfungsi sebagai alat hiburan. Dengan demikian, tidak diperkenankan menggunakannya hanya sekedar untuk permainan ataumemancing perhatian

\footnotetext{
${ }^{13}$ Hamzah Uno, Perencanaan Pembelajaran, (Jakarta: Bumi Aksara, 2009), 209.

14 Mark Smith, Teori Pembelajaran dan Pengajaran, (Jogjakarta: Mirza Media Pustaka, 2009), 84.

15 Isjoni, Cooperative Learning: Efektivitas Pembelajaran Kelompok, (Bandung: Alfabeta, 2012), 14.

${ }^{16}$ Trianto, Model-model Pembelajaran Inovatif Berorientasi Konstruktivistik, (Jakarta: Prestasi Pustaka, 2007), 41.

17 Azhar Arsyad, Media Pembelajara. (Jakarta: Rajawali Pers, 2011), 4.
} 
siswa semata; (5) Media pembelajaran bisa berfungsi untuk meningkatkan kualitas proses belajar mengajar; dan (6) Media pembelajaran meletakkan dasar-dasar yang konkret untuk berpikir. ${ }^{18}$ Oleh karena itu, dapat mengurangi terjadinya penyakit verbalisme.

Jadi dapat disimpulkan bahwa media pembelajaran memiliki fungsi sebagai perantara atau sarana yang tidak hanya dijadikan sebagai alat hiburan melainkan dijadikan sebagai sarana yang efektif untuk membantu kegiatan belajar mengajar dengan mengaktifkan siswa dalam kegiatan pembelajaran sehingga kualitas proses belajar mengajar tercapai secara optimal.

\section{Media Pembelajaran Audio visual}

Menurut Hamdani media pembelajaran dikelompokkan menjadi tiga jenis, yaitu: (1) Media visual; (2) Meia audio; dan (3) Media audiovisual. ${ }^{19}$ Menurut Anitah media audiovisual merupakan kombinasi audio dan visual atau bisaa disebut media pandang dengar. Apabila menggunakan media ini akan semakin lengkap dan optimal penyajian bahan ajar kepada para siswa, selain itu media ini dalam batas-batas tertentu dapat juga menggantikan peran dan tugas guru.

Arsyad (juga menjelaskan bahwa pengajaran melalui audiovisual adalah produksi dan penggunaan materi yang penyer apannya melalui pandangan dan pendengaran serta tidak seluruhnya tergantung kepada pemahaman kata atau simbol-simbol yang serupa. Dale dalam Arsyad mengemukakan bahwa bahanbahan audio-visual dapat memberikan banyak manfaat asalkan guru berperan aktif dalam proses pembelajaran. ${ }^{20}$

Djamarah mengemukakan bahwa media audiovisual adalah media yang mempunyai unsur suara dan unsur gambar. Jenis media ini mempunyai kemampuan yang lebih baik, karena meliputi kedua jenis media yang pertama dan kedua. Media ini dibagi lagi ke dalam :21

a. Audiovisual Diam, yaitu media yang menampilkan suara dari gambar diam seperti film bingkai suara (soundslide), film rangkai suara, dan cetak suara.

b. Audiovisual Gerak, yaitu media yang dapat menampilkan unsur suara dan gambar yang bergerak seperti film suara dan video cassete.

Kaitan penggunaan media audio visual berupa video dalam penelitian yang akan dilakukan yaitu peneliti mengombinasikan penggunaan video dengan materi dalam pembelajaran Sejarah Indonesia di kelas XI. Adapun durasi video yang ditayangkan adalah 5-8 menit. Video dapat digunakan untuk memaparkan keadaan riil dari suatu proses, fenomena atau kejadian sehingga dapat memperkaya pemaparan. Jadi melalui penggabungan ini diharapkan system pembelajaran akan lebih inovatif, mampu menimbulkan rasa senang dan minat peserta didik untuk aktif terlibat dalam kegiatan pembelajaran serta peserta didik akan lebih mudah memahami materi yang disampaikan.

Berdasarkan beberapa pendapat di atas, dapat disimpulkan bahwa media audio visual merupakan media yang melibatkan dua hal yaitu penglihatan dan pendengaran. Dalam kegiatan pembelajaran, penggunaan media audio visual

\footnotetext{
${ }^{18}$ Sri Anitah W., Strategi Pembelajaran di SMA, (Jakarta: Universitas Terbuka, 2009), 2.90.

${ }^{19}$ Hamdani, Strategi Belajar Mengajar, (Bandung: Pustaka Setia, 2010), 248.

20 Azhar Arsyad, Media Pembelajaran, (Jakarta: Rajawali Pers, 2011), 23.

${ }^{21}$ Djamarah, Strategi Belajar Mengajar, (Jakarta: Rineka Cipta, 2010), 124.
} 
memiliki tingkat keefektifan yang tinggi karena proses penyajian bahan ajar kepada peserta didik lebih lengkap, tidak hanya secara visual ataupun secara audio saja namun merupakan gabungan keduanya. Keberhasilan dalam pengajaran menggunakan media audio visual juga sangat dipengaruhi oleh keaktifan guru untuk terlibat dalam proses pembelajaran.

\section{Metode Penelitian Jenis Penelitian}

Rancangan yang ditetapkan dalam penelitian ini adalah Penelitian Tindakan Kelas. Menurut Aqib penelitian Tindakan Kelas (PTK) adalah penelitian yang dilakukan oleh guru di kelasnya sendiri melalui refleksi diri dengan tujuan untuk memperbaiki kinerjanya sehingga hasil belajar siswa meningkat. ${ }^{22}$

Menurut Arikunto secara garis besar untuk melaksanakan Penelitian Tindakan Kelas (PTK) terdapat empat tahapan yang lazim dilalui, yaitu : 1) perencanaan, 2) pelaksanaan, 3) pengamatan, dan 4) refleksi. Keempat tahap dalam penelitian tindakan tersebut adalah unsur untuk membentuk sebuah siklus, yaitu satu putaran kegiatan beruntun, yang kembali ke arah semula. ${ }^{23}$

\section{Teknik Pengumpulan Data}

Teknik pengumpulan data yang digunakan dalam penelitian ini meliputi teknik tes dan teknik nontes.

1. Teknik Tes. Tes merupakan himpunan pertanyaan yang harus dijawab, harus ditanggapi atau tugas yang harus dilaksanakan oleh orang yang dites. Tes digunakan untuk mengukur sejauh mana seorang siswa telah menguasai pelajaran yang disampaikan terutama meliputi aspek pengetahuan dan keterampilan.

Tes dalam penelitian ini dilaksanakan pada akhir pembelajaran setiap siklus, yaitu dari siklus pertama hingga siklus kedua untuk mengukur tingkat pencapaian siswa setelah mempelajari materi pembelajaran Sejarah Indonesia menggunakan model Snowball Throwing dengan media Audio Visual. Bentuk instrumen tes yang diberikan berupa soal pilihan ganda dan essay.

2. Teknik Non tes. Teknik non tes yang digunakan dalam penelitian ini yaitu observasi, wawancara, dokumentasi dan catatan lapangan. Observasi. Instrumen observasi yang digunakan dalam penelitian ini berupa lembar pengamatan yang digunakan untuk mengamati keterampilan guru dan aktivitas siswa dalam kegiatan pembelajaran Sejarah Indonesia menggunakan model Snowball Throwing dengan media Audio Visual. Wawancara. Teknik wawancara yang dilakukan dalam penelitian ini adalah wawancara bebas dimana peneliti telah menyiapkan dan membuat daftar pertanyaan yang akan diajukan kepada guru sebagai responden dan memberikan kebebasan kepada guru untuk mengemukakan pendapatnya. Wawancara ini ditujukan kepada guru untuk mengetahui pendapat guru mengenai penerapan model Snowball Throwing dengan media Audio Visual dalam pembelajaran Sejarah Indonesia. Dokumentasi. Dokumen yang digunakan dalam penelitian ini berupa daftar kelompok siswa dan daftar nilai siswa. Untuk memberikan gambaran secara konkret mengenai kegiatan kelompok siswa dan

\footnotetext{
22 Zainal Aqib, Penelitian Tindakan Kelas, (Bandung: Yrama Widya, 2011), 3.

${ }^{23}$ Suharsimi Arikunto, Penelitian Tindakan Kelas, (Jakarta: Sinar Grafika, 2008), 131.
} 
menggambarkan suasana kelas ketika aktivitas belajar berlangsung digunakan dokumen berupa foto dan video.

\section{Hasil Penelitian}

Rekapitulasi data hasil observasi aktivitas siswa pada siklus II yang meliputi pertemuan I dan pertemuan II akan ditunjukkan pada tabel dan gambar di bawah ini:

Tabel Hasil Observasi Aktivitas Siswa Pada Siklus II

\begin{tabular}{|c|c|c|c|c|}
\hline \multirow[b]{2}{*}{ No. } & \multirow[b]{2}{*}{ Indikator } & \multicolumn{2}{|c|}{ Skor yang didapatkan } & \multirow[b]{2}{*}{$\begin{array}{l}\text { Rata-rata } \\
\text { skor Siklus II }\end{array}$} \\
\hline & & $\begin{array}{c}\text { Pertemuan } \\
\text { I }\end{array}$ & $\begin{array}{l}\text { Pertemuan } \\
\text { II }\end{array}$ & \\
\hline 1 & $\begin{array}{l}\text { Mempersiapkan diri dalam } \\
\text { menerima pelajaran }\end{array}$ & 2,7 & 3,1 & 2,9 \\
\hline 2 & $\begin{array}{l}\text { Memperhatikan tayangan } \\
\text { video }\end{array}$ & 2,6 & 2,7 & 2,65 \\
\hline 3 & $\begin{array}{l}\text { Siswa duduk secara } \\
\text { berkelompok }\end{array}$ & 3,1 & 3,2 & 3,15 \\
\hline 4 & $\begin{array}{l}\text { Ketua kelompok menjelaskan } \\
\text { materi dan anggota kelompok } \\
\text { menyimak materi }\end{array}$ & 2,4 & 2,7 & 2,6 \\
\hline 5 & Membuat bola pertanyaan & 3,1 & 3,3 & 3,2 \\
\hline 6 & Melakukan diskusi kelompok & 3 & 3,4 & 3,2 \\
\hline 7 & $\begin{array}{l}\text { Mempresentasikan hasil } \\
\text { diskusi }\end{array}$ & 2,5 & 3 & 2,75 \\
\hline 8 & Menanggapi hasil diskusi & 2,3 & 2,8 & 2,55 \\
\hline 9 & Mengerjakan soal evaluasi & 3 & 3,4 & 3,2 \\
\hline \multicolumn{2}{|r|}{ Jumlah Skor Keseluruhan } & 24,7 & 27,6 & 26,2 \\
\hline & Kategori & Baik & $\begin{array}{l}\text { Sangat } \\
\text { Baik }\end{array}$ & Baik \\
\hline
\end{tabular}

Aktivitas Siswa Pada Siklus II

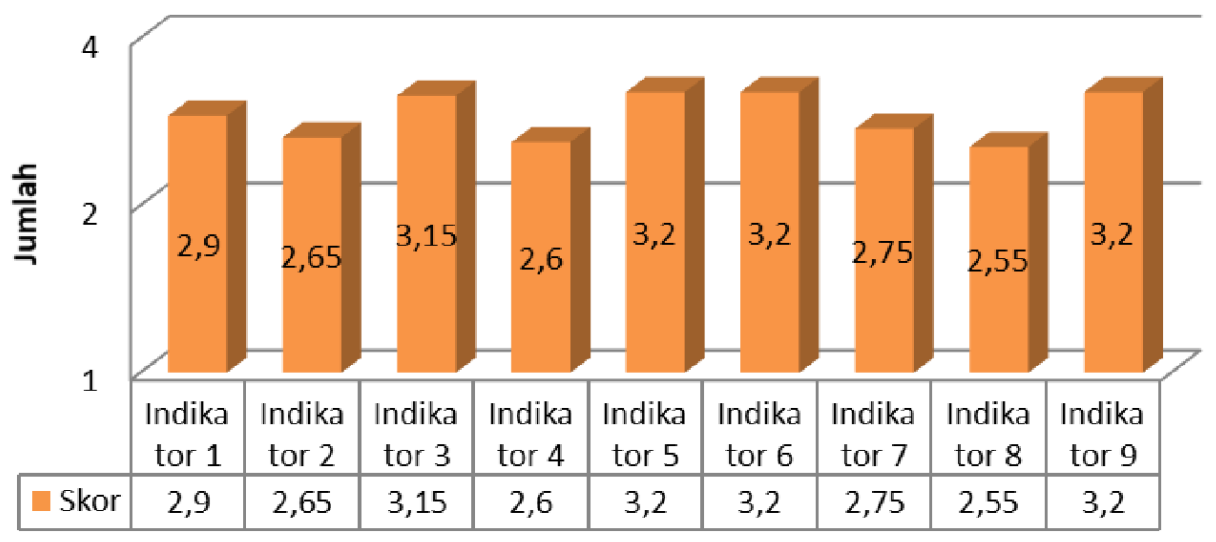

Berdasarkan tabel dan diagram di atas mengenai data hasil observasi aktivitas siswa pada siklus II, ditunjukkan bahwa jumlah skor keseluruhan aktivitas siswa adalah 26,2 dengan kategori baik. Dengan demikian dapat dikatakan bahwa 
aktivitas siswa telah mengalami ketuntasan karena telah mencapai indikator keberhasilan yang ditetapkan yaitu sekurang-kurangnya baik.

\section{Rekapitulasi Data Hasil Belajar Siswa Siklus II}

Rekapitulasi data hasil belajar siswa pada siklus II yang meliputi pertemuan I dan pertemuan II akan ditunjukkan pada tabel dan gambar di bawah ini:

Tabel Data Hasil Belajar Siswa Pada Siklus II

\begin{tabular}{|l|l|c|c|c|}
\hline \multirow{2}{*}{ No. } & \multicolumn{1}{|c|}{ Aspek } & \multicolumn{3}{|c|}{ Skor yang didapatkan } \\
\cline { 3 - 5 } & & $\begin{array}{c}\text { Pertemuan } \\
\text { I }\end{array}$ & $\begin{array}{c}\text { Pertemuan } \\
\text { II }\end{array}$ & Rerata \\
\hline 1 & Nilai Tertinggi & 96,7 & 100 & 98,35 \\
\hline 2 & Nilai Terendah & 46,7 & 50 & 48,35 \\
\hline 3 & Jumlah Siswa Tuntas & 30 & 34 & 33 \\
\hline 4 & Jumlah Siswa Tidak Tuntas & 9 & 5 & 6 \\
\hline 5 & Rata-rata & 78,74 & 85,13 & 81,93 \\
\hline 6 & Persentase Ketidak Tuntasan & $23,08 \%$ & $12,82 \%$ & $15,38 \%$ \\
\hline 7 & Persentase Ketuntasan & $76,92 \%$ & $87,18 \%$ & $84,62 \%$ \\
\hline
\end{tabular}

Berdasarkan tabel dan diagram batang di atas mengenai data hasil belajar siswa pada siklus II ditunjukkan bahwa persentase ketuntasan secara klasikal hasil belajar siswa pada siklus II adalah 84,62 \% dengan rata-rata 81,93. Dengan demikian, hasil belajar siswa pada siklus II dapat dikatakan telah mengalami ketuntasan karena berhasil mencapai indikator keberhasilan yang ditetapkan yaituketuntasan secara klasikal sebesar $80 \%$.

\section{Pembahasan}

Pemaknaan temuan hasil penelitian didasarkan pada hasil penelitian yang diperoleh dari observasi keterampilan guru, observasi aktivitas siswa serta hasil belajar siswa didukung dengan data catatan lapangan dan hasil wawancara dalam pembelajaran Sejarah Indonesia menggunakan model Snowball Throwing dengan media Audio Visual di kelas XI-MIPA-3 SMA Negeri 2 Sampang pada setiap siklusnya terhadap peningkatan kualitas pembelajaran. Berikut ini pembahasan secara rinci mengenai temuan penelitian pada tiap siklusnya :

\section{Hasil Observasi Peningkatan Keterampilan Guru}

Hasil observasi keterampilan guru dalam pembelajaran Sejarah Indonesia menggunakan model Snowball Throwing dengan media Audio Visual pada siklus I ke siklus II mengalami peningkatan. Hasilnya dapat dilihat pada tabel berikut:

Tabel Rekapitulasi Hasil Observasi Keterampilan Guru Pada Siklus I dan Siklus II 


\begin{tabular}{|c|l|c|c|}
\hline \multirow{2}{*}{ No } & \multicolumn{1}{|c|}{ Indikator Keterampilan Guru } & \multicolumn{2}{c|}{ Pencapaian Skor } \\
\cline { 3 - 4 } & \multicolumn{1}{|c|}{ Siklus 1 } & Siklus 2 \\
\hline 1 & $\begin{array}{l}\text { Mengondisikan siswa agar siap } \\
\text { mengikuti kegiatan pembelajaran }\end{array}$ & 2,5 & 4 \\
\hline 2 & $\begin{array}{l}\text { Melakukan apersepsi sesuai } \\
\text { dengan materi yang akan diajarkan }\end{array}$ & 2 & 3 \\
\hline 3 & $\begin{array}{l}\text { Menyampaikan tujuan } \\
\text { pembelajaran }\end{array}$ & 4 & 4 \\
\hline 4 & $\begin{array}{l}\text { Menampilkan media Audio Visual } \\
\text { berupa Video dalam kegiatan } \\
\text { pembelajaran }\end{array}$ & 2 & 3,5 \\
\hline 5 & $\begin{array}{l}\text { Menjelaskan materi yang ada } \\
\text { dalam media Audio Visual }\end{array}$ & 2,5 & 3,5 \\
\hline 6 & Membentuk kelompok diskusi & 1,5 & 2,5 \\
\hline 7 & $\begin{array}{l}\text { Menjelaskan materi kepada ketua } \\
\text { kelompok }\end{array}$ & 3 & 4 \\
\hline 8 & $\begin{array}{l}\text { Membimbing siswa untuk } \\
\text { membuat bola pertanyaan }\end{array}$ & 2,5 & 3,5 \\
\hline 9 & Membimbing diskusi kelompok & 1,5 & 2 \\
\hline 10 & $\begin{array}{l}\text { Memberikan penguatan kepada } \\
\text { siswa }\end{array}$ & $\mathbf{1 5 , 5}$ & $\mathbf{3 5 , 5}$ \\
\hline 11 & Menutup kegiatan pembelajaran & $\begin{array}{c}\text { Sangat } \\
\text { Baik }\end{array}$ \\
\hline & Kumlah & 2,5 \\
\hline & & 2,5 & 3 \\
\hline
\end{tabular}

Keterampilan Guru Siklus I dan Siklus II

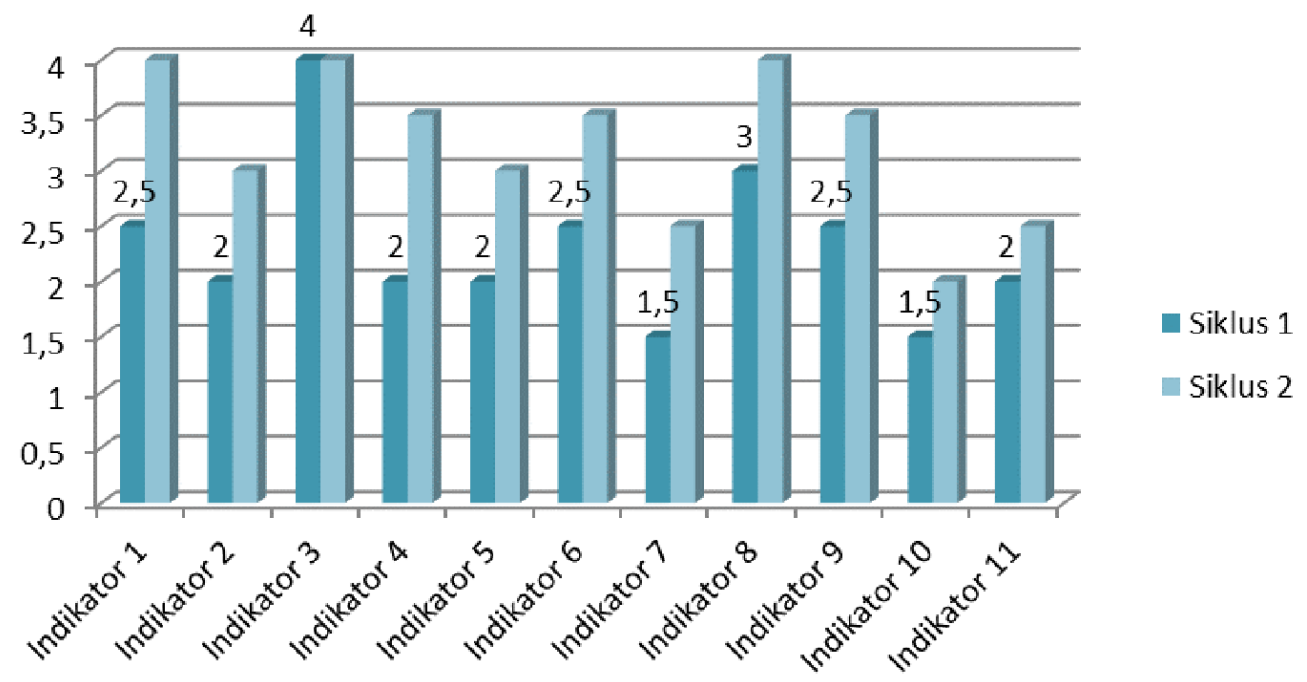

Berdasarkan tabel dan digram batang di atas yang menggambarkan rekapitulasi hasil observasi keterampilan guru dalam pembelajaran Sejarah Indonesia menggunakan model Snowball Throwing dengan menggunakan media Audio Visual dari siklus I hingga siklus II, dapat dijabarkan secara rinci 
peningkatan keterampilan guru tersebut pada masing-masing indikator sebagai berikut:

Hasil observasi aktivitas siswa pada pembelajaran Sejarah Indonesia menggunakan model Snowball Throwing dengan media Audio Visual mengalami peningkatan pada siklus I ke siklus II. Hasil tersebut dapat dilihat dari tabel dan diagram berikut ini:

Tabel Rekapitulasi Hasil Observasi Aktivitas Siswa Pada Siklus I ke Siklus II

\begin{tabular}{|c|l|c|c|}
\hline \multirow{2}{*}{ No } & \multicolumn{1}{|c|}{ Indikator Keterampilan Guru } & \multicolumn{2}{c|}{ Pencapaian Skor } \\
\cline { 3 - 4 } & \multicolumn{1}{|c|}{$\begin{array}{c}\text { Siklus 1 } \\
\text { Mempersiapkan diri dalam menerima } \\
\text { pelajaran }\end{array}$} & 2 & 2,9 \\
\hline 2 & Memperhatikan tayangan video & 2,1 & 2,65 \\
\hline 3 & Siswa duduk secara berkelompok & 2,7 & 3,15 \\
\hline 4 & $\begin{array}{l}\text { Ketua kelompok menjelaskan materi } \\
\text { dan anggota kelompok menyimak } \\
\text { materi }\end{array}$ & 1,9 & 2,6 \\
\hline 5 & Membuat bola pertanyaan & 2,95 & 3,2 \\
\hline 6 & Melakukan diskusi kelompok & 2,3 & 3,2 \\
\hline 7 & Mempresentasikan hasil diskusi & 2 & 2,75 \\
\hline 8 & Menanggapi hasil diskusi & 1,85 & 2,55 \\
\hline 9 & Mengerjakan soal evaluasi & 2,5 & 3,2 \\
\hline & Jumlah & 20,3 & 26,2 \\
\hline & Kategori & Baik & Baik \\
\hline
\end{tabular}

Keterampilan Guru Siklus I dan Siklus II

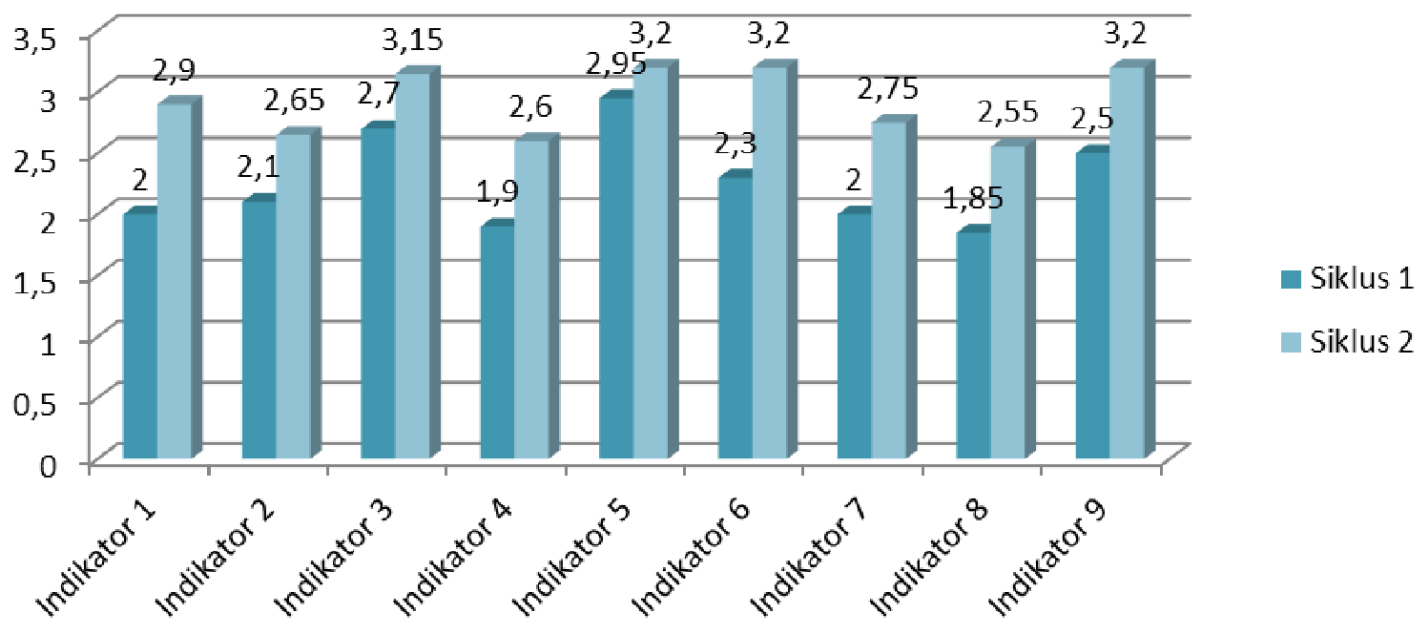

Diagram Batang Rekapitulasi Hasil Observasi Aktivitas Siswa

Pada Siklus I dan Siklus II

Berdasarkan tabel dan diagram batang di atas yang menggambarkan rekapitulasi hasil observasi aktivitas siswa pada siklus I ke siklus II dalam 
pembelajaran Sejarah Indonesia menggunakan model Snowball Throwing dengan media Audio Visual, dapat diketahui bahwa aktivitas siswa pada siklus I ke siklus II mengalami peningkatan pada setiap indikatornya dengan penjabaran sebagai berikut :

Hasil belajar siswa dalam pembelajaran Sejarah Indonesia menggunakan model Snowball Throwing dengan media Audio Visual mengalami peningkatan dari siklus I ke siklus II, berikut ini akan dijabarkan peningkatan hasil belajar siswa dari siklus I ke siklus II melalui tabel di bawah ini:

Tabel Peningkatan Hasil Belajar Siswa dalam Pembelajaran Sejarah Indonesia Pada Data Awal, Siklus I dan Siklus II

\begin{tabular}{|c|l|c|c|c|}
\hline \multirow{2}{*}{ No } & \multicolumn{1}{|c|}{ Aspek } & \multicolumn{3}{|c|}{ Pencapaian } \\
\cline { 3 - 5 } & & Data Awal & Siklus 1 & Siklus 2 \\
\hline 1 & Nilai Tertinggi & 87.5 & 86.7 & 98.35 \\
\hline 2 & Nilai Terendah & 40 & 51.65 & 48.35 \\
\hline 3 & Jumlah Siswa Tuntas & 15 & 27 & 33 \\
\hline 4 & $\begin{array}{l}\text { Jumlah Siswa Tidak } \\
\text { Tuntas }\end{array}$ & 24 & 12 & 6 \\
\hline 5 & Rata-rata & 63,3 & 67.69 & 81.93 \\
\hline 6 & $\begin{array}{l}\text { Persentase Ketidak } \\
\text { Tuntasan }\end{array}$ & $61.54 \%$ & $30.77 \%$ & $15.38 \%$ \\
\hline 7 & Persentase Ketuntasan & $38.46 \%$ & $69.23 \%$ & $84.62 \%$ \\
\hline
\end{tabular}

Berdasarkan tabel di atas, digambarkan bahwa hasil belajar siswa pada pembelajaran Sejarah Indonesia menggunakan model Snowball Throwing dengan media Audio Visual dari data awal, siklus I hingga siklus II mengalami peningkatan ditunjukkan dengan perolehan rata-rata nilai siswa pada data awal yaitu 63,3 dengan prosentase ketuntasan secara klasikal yaitu 38,64 \%, kemudian meningkat rata-ratanya menjadi 67,69 dengan persentase ketuntasan secara klasikal yaitu 69,23 \% pada siklus I, dilanjutkan dengan siklus II yaitu dengan rata-rata nilai yang didapatkan meningkat menjadi 81,93 dengan persentase ketuntasan secara klasikal adalah 84,62 \%. Dari data tersebut, dapat disimpulkan bahwa hasil belajar siswa pada siklus II dapat dikatakan mengalami ketuntasan karena telah mencapai indikator keberhasilan yang telah ditetapkan yaitu ketuntasan belajar secara klasikal adalah $80 \%$, dengan demikian penelitian telah berakhir pada siklus II.

Pada penelitian ini, model pembelajaran yang diterapkan guru dalam pembelajaran Sejarah Indonesia di kelas XI-MIPA-3 SMA Negeri 2 Sampang adalah model pembelajaran kooperatif tipe Snowball Throwing dengan media Audio visual. Peningkatan hasil belajar siswa disebabkan karena guru telah merancang pembelajaran yang menarik dengan didasarkan atas prinsip dan asas kegiatan pembelajaran kooperatif disertai dengan penggunaan media Audio Visual yang menarik sehingga dapat memotivasi dan meningkatkan antusiasme siswa dalam mengikuti kegiatan pembelajaran. Hal ini sesuai dengan pendapat Suprijono bahwa model pembelajaran kooperatif dikembangkan untuk mencapai hasil belajar berupa prestasi akademik, toleransi, menerima keragaman, dan pengembangan keterampilan sosial. Selain itu, sesuai dengan pendapat Uno dan 
Mohammad bahwa tugas utama seorang guru adalah untuk memudahkan pembelajaran para pelajar. Untuk memenuhi tugas ini, guru bukan saja harus dapat menyediakan suasana pembelajaran yang menarik dan harmonis, tetapi juga menciptakan pembelajaran yang berkesan. Hal ini bermakna bahwa guru perlu mewujudkan suasana pembelajaran yang dapat merangsang minat belajar untuk terlibat aktif dalam kegiatan pembelajaran. Salah satu cara yang bisa dilakukan guru yaitu dengan menyediakan sumber belajar yang menarik seperti penggunaan media yang mampu menarik perhatian siswa dalam mengikuti kegiatan pembelajaran sehingga berpengaruh terhadap hasil belajar yang dicapai oleh siswa.

Berdasarkan uraian di atas mengenai peningkatan keterampilan guru dan aktivitas siswa yang berpengaruh terhadap peningkatan hasil belajar siswa dalam pembelajaran Sejarah Indonesia. membuktikan bahwa model pembelajaran Snowball Throwing dengan media Audio Visual yang dipilih oleh peneliti, cocok diterapkan dalam pembelajaran Sejarah Indonesia pada siswa kelas XI-MIPA-3 SMA Negeri 2 Sampang Kabupaten Sampang.

\section{Kesimpulan}

Berdasarkan hasil penelitian dan pembahasan mengenai peningkatan kualitas pembelajaran Sejarah Indonesia menggunakan model Snowball Throwing dengan media Audio Visual siswa kelas XI-MIPA-3 SMA Negeri 2 Sampang, dapat disimpulkan bahwa: Model Snowball Throwing dengan media Audio Visual dapat meningkatkan keterampilan guru dalam pembelajaran Sejarah Indonesia siswa kelas XI-MIPA-3 SMA Negeri 2 Sampang. Hal ini dibuktikan dari hasil observasi keterampilan guru selama penelitian yang menunjukkan adanya peningkatan skor pada tiap siklusnya, yaitu pada siklus I rata-rata skor yang diperoleh guru adalah 25,5 dengan kategori baik dan meningkat menjadi 35,5 dengan kategori sangat baik pada siklus II; Model Snowball Throwing dengan media Audio Visual dapat meningkatkan aktivitas siswa dalam pembelajaran Sejarah Indonesia di kelas XIMIPA-3 SMAN 2 Sampang. Hal ini dibuktikan dari hasil observasi aktivitas siswa selama penelitian yang menunjukkan adanya peningkatan skor pada tiap siklusnya, yaitu pada siklus I rata-rata skor yang diperoleh siswa adalah 20,3 dengan kategori baik dan meningkat menjadi 26,2 dengan kategori baik pada siklus II; Model Snowball Throwing dengan media Audio Visual dapat meningkatkan hasil belajar siswa dalam pembelajaran Sejarah Indonesia di kelas XI-MIPA-3 SMA Negeri 2 Sampang. Hal ini dibuktikan dengan adanya peningkatan persentase ketuntasan klasikal hasil belajar siswa dan rata-rata nilai yang didapatkan pada setiap siklusnya, yaitu pada siklus I persentase ketuntasan klasikal hasil belajar siswa adalah 69,23 \% dengan rata-rata 67,69 dan meningkat pada siklus II yaitu ketuntasan secara klasikal sebanyak 84,62 \% dengan rata-rata $81,93$.

Dari simpulan di atas dapat diketahui bahwa hipotesis tindakan dari penelitian ini telah terjawab, yaitu jika model Snowball Throwing dengan media Audio Visual diterapkan dalam pembelajaran Sejarah Indonesia siswa kelas XIMIPA-3 SMAN 2 Sampang, maka kualitas pembelajaran yang ditandai dengan keterampilan guru, aktivitas siswa dan hasil belajar siswa dapat meningkat. 


\section{Daftar Pustaka}

Anitah W, Sri, Strategi Pembelajaran di SM, (Jakarta: Universitas Terbuka, 2009)

Arikunto, Suharsimi, dkk. Penelitian Tindakan Kelas. (Jakarta: Sinar Grafika, 2008)

Arsyad, Azhar, Media Pembelajaran. (Jakarta: Rajawali Pers, 2011).

Aqib, Zainal, Penelitian Tindakan Kelas, (Bandung: Yrama Widya, 2011).

BSNP, Permendiknas RI Nomor 41 Tahun 2007, (Jakarta: BSNP, 2007).

Djamarah, Syaiful Bahri dan Aswan Zain, Strategi Belajar Mengajar, (Jakarta:

Rineka Cipta, 2010).

Depdiknas, Peningkatan Kualitas Pembelajaran, (Jakarta: Depdiknas, 2004).

Hamalik, Oemar, Proses Belajar Mengajar. (Jakarta: Bumi Aksara, 2012).

Hamdani, Strategi Belajar Mengajar. (Bandung: Pustaka Setia, 2011).

Isjoni, Cooperative Learning: Efektivitas Pembelajaran Kelompok. (Bandung: Alfabeta, 2012).

Jihad, Asep dan Abdul Haris, Evaluasi Pembelajaran, (Yogyakarta: Multi Pressindo, 2008).

Komalasari, Pembelajaran Kontekstual Konsep dan Aplikasi, (Bandung: Refika Aditama, 2011).

Mulyasa, Praktik Penelitian Tindakan Kelas, (Bandung: Remaja Rosdakarya, 2011).

Rusman, Model-model Pembelajaran, (Jakarta: Rajawali Pers, 2012).

Sardiman, Interaksi dan Motivasi Belajar Mengajar, (Jakarta:Rajawali Pers, 2011).

Slameto, Belajar dan Faktor-faktor yang Mempengaruhinya, (Jakarta: Rineka Cipta, 2010).

Smith, Mark K, Teori Pembelajaran dan Pengajaran, (Jogjakarta: Mirza Media Pustaka, 2009).

Sudjana, Nana, Penilaian Hasil Proses Belajar Mengajar, (Bandung: PT Remaja Rosdakarya, 2012).

Sukiman, Pengembangan Media Pembelajaran, (Yogyakarta: Pedagogia, 2012).

Trianto, Model-model Pembelajaran Inovatif Berorientasi Konstruktivistik, (Jakarta: Prestasi Pustaka, 2007).

Uno, Hamzah B, Perencanaan Pembelajaran, (Jakarta: Bumi Aksara, 2009).

Wardhani, IGAK dan Kuswaya Wihardit. Penelitian Tindakan Kelas, (Jakarta: Universitas Terbuka, 2008). 